Research Article

\title{
Cowry shells of Andrew Bay in Rakhine coastal region of Myanmar
}

\begin{abstract}
A total of 21 species of cowry shells belonging to genus Cypraea Linnaeus 1758 of family Cypraeidae falling under the order Mesogastropoda collected from field observation in 2014, were identified, using liquid-preserved materials and living specimens in the field, based on the external characters of shell structures. The specimens comprised Cypraea tigris Linnaeus, 1758, C. miliaris Gmelin, 1791, C. mauritiana Linnaeus, 1758, C. thersites Gaskoin, 1849, C. arabica Linnaeus, 1758, C. scurra Gmelin, 1791, C. eglantina Duclos, 1833, C. talpa Linnaeus, 1758, C. argus Linnaeus, 1758, C. erosa Linnaeus, 1758, C. labrolineata Gaskoin, 1849, C. caputserpentis Linnaeus, 1758, C. nucleus Linnaeus, 1758, C. isabella Linnaeus, 1758, C. cicercula Linnaeus, 1758, C. globulus Linnaeus, 1758, C. lynx Linnaeus, 1758, C. asellus Linnaeus, 1758, C. saulae Gaskoin, 1843, C. teres Gmelin, 1791 and C. reevei Gray, 1832. The distribution, habitats and distinct ecological notes of cowry shells in intertidal and subtidal zone of Andrew Bay and adjacent coastal areas were studied in brief.
\end{abstract}

Keywords: Andrew Bay, cowry shells, cypraeidae, gastropod, Rakhine Coastal Region
Volume 7 Issue 4 - 2019

\author{
Naung Naung Oo \\ Department of Marine Science, Mawlamyine University, \\ Myanmar
}

\author{
Correspondence: Naung Naung Oo,Assistant \\ Lecturer, Department of Marine Science, Mawlamyine \\ University, Myanmar, Email ricardo.garcia.mayor@sergas.es \\ rvgarciamayor@hmhopitales.com
}

Received: July 06, 2019 | Published: August 12, 2019

\section{Introduction}

The literature of the molluscs is vast in other countries but in Myanmar only few books are available for reference work. Consequently, it is found that there have been relatively very few works that deal with Myanmar molluscs in the past. The earliest work on Myanmar molluscs is that of Mason. ${ }^{1-3}$ Mason's books covered almost all branches of science that could be investigated at that time. As far as molluscs were concerned he was able to divide into 4 classes, 2 subclasses, 7 orders, 84 families, 15 subfamilies and 710 species. However, Mason had collected his fauna not only from the Taninthayi Coastal Region but also from the Rakhine Coastal Region in the north. The next appreciable earlier publication on Myanmar molluscs appeared by Mann. ${ }^{4}$ It was fairly up to date literature on shells available for serious students of molluses of the world. In this way there were entire lack of modern literatures on Myanmar molluscs and information gained from these literatures were very scare and inadequate. Soe $\mathrm{Thu}^{5-7}$ had recorded the diversity of seashells from Ngapali, Maungmagan and various localities of Myanmar coastal waters.

Consequently, Kyaw Myint ${ }^{8}$ had published a checklist comprising of 153 species of marine gastropods. The list includes 42 families which however is not yet a complete checklist for Myanmar. Maung Win et.al ${ }^{9}$ had also reported the morphology and taxonomy of some marine molluscs found in the coastal waters of Myanmar. Moreover, Phyu Phyu Khin Win ${ }^{10}$ had studied the taxonomy of some molluscs trawled offshore in Myanmar waters. Subsequently, Naung Naung $\mathrm{Oo}^{11}$ reported the distribution of marine gastropods in Mon coastal water of Myanmr. Moreover, a systematic account on some gastropods and pelecypods in various localities of Myanmar had been carried out by Aye Thant Zin et.al, ${ }^{12}$ Thaw Zin Naing Tun et.al, ${ }^{13}$ Phoo Thet Su Win, ${ }^{14}$ Su Pyae Tun ${ }^{15}$ and Aung Ko Latt. ${ }^{16}$
The Cypraeidae are tropical gastropods with the majority of species found in the Indo-Pacific region; only 25 species are present in the Western Central Pacific. ${ }^{17}$ There are Cypraea annulus Linnaeus, 1758; C. arabica Linnaeus, 1758; C. argus Linnaeus, 1758; C. bouteti Burgess and Arnette, 1981; C. caputserpentis Linnaeus, 1758; C. carneola Linnaeus, 1758; C. caurica Linnaeus, 1758; C. depressa Gray, 1824; C. eglantina Duclos, 1833; C. erosa Linnaeus, 1758; C. isabella Linnaeus, 1758; C. leviathan (Schilder and Schilder, 1937); C. lynx Linnaeus, 1758; C. maculifera Schilder, 1932; C. mappa Linnaeus, 1758; C. mauritiana Linnaeus, 1758; C. moneta Linnaeus, 1758; C. obvelata Lamarck, 1810; C. onyx Linnaeus, 1758; C. schilderorum Iredale, 1939; C. scurra Gmelin, 1791; C. talpa Linnaeus, 1758; C. tigris Linnaeus, 1758; C. ventriculus Lamarck, 1810 and C. vitellus Linnaeus, 1758.

In Myanmar, there were 31 species of Cypraea, namely C. tigris Linnaeus, 1758; C. miliaris Gmelin, 1791; C. turdus Lamarck, 1810; C. mauritiana Linnaeus, 1758; C. thersites Gaskoin, 1849; C. arabica Linnaeus, 1758; C. scurra Gmelin, 1791; C. eglantina Duclos, 1833; C. talpa Linnaeus, 1758; C. argus Linnaeus, 1758; C. vanelli Linnaeus, 1758; C. carneola Linnaeus, 1758; C. vitellus Linnaeus, 1758; C. annulus Linnaeus, 1758; C. moneta Linnaeus, 1758; C. erosa Linnaeus, 1758; C. labrolineata Gaskoin, 1849; C. caputserpentis Linnaeus, 1758; C. nucleus Linnaeus, 1758; C. errones Linnaeus, 1758; C. caurica Linnaeus, 1758; C. clandestina Linnaeus, 1758; C. cribaria Linnaeus, 1758; C. isabella Linnaeus, 1758; C. cicercula Linnaeus, 1758; C. globulus Linnaeus, 1758; C. lynx Linnaeus, 1758; C. asellus Linnaeus, 1758; C. saulae Gaskoin, 1843; C. teres Gmelin, 1791 and $C$. reevei Gray, 1832 had been reported by Soe Thu. ${ }^{7}$ Likewise, 2 species of Cypraea, namely C. eglantina Duclos, 1833 and C. peasei (G. B. Sowerby III, 1870) had been reported by Naung Naung $\mathrm{Oo}^{11}$ based on morphological and some ecological features collected from various coastal areas of Mon State. 
The objective of this study is to determine the distribution, habitats and distinct ecological notes of cowry shells in intertidal and subtidal zone of Andrew Bay and adjacent coastal areas.

\section{Materials and methods}

Some cowry shells were collected in the forms of drift and live specimens living in intertidal and shallow subtidal areas such as Geik Taw, Pearl Is., Thanban Gyaing, Abae Chaung, Thanbayar Gyaing, Mayoe Bay, Kathit Is., Thabyu Gyaing, Ponenyat Gyaing, Kwinwine Gyaing, Kyauk pone gyi hmaw and Maung shwe lay Gyaing around the Andrew Bay, Rakhine State (Figure 1) during the field trip in 2014

All collections were preserved in $10 \%$ formalin in seawater. The epifaun as were removed by soaking the shells in a solution of caustic soda and then cleaned, washed, dried, and ready for storage, they are lightly rubbed with a small amount of oil applied with a brush to make them fresh-looking in a slight luster to the surface, and aid in presenting the delicate colouring for further study.

All voucher specimens were deposited at the Museum of the Department of Marine Science, Mawlamyine University (MLM.MS). Zoogeographical distribution of each species was prepared with the data from the literature available. Ecological notes and associated species of these molluscs were also recorded in the field.

\section{Results and discussion}

The cowry shells, locally called 'Kywe-poke' were conducted from 12 collection sites at Andrew Bay and its vicinity in Rakhine Coastal Region. In this study, a total of 21 species of cowry shells were observed from different habitats at intertidal and shallow subtidal levels, to a depth of about $45 \mathrm{~m}$. This systematic account follows the identifying set out by Burgess, ${ }^{18}$ Lorenz and Hubert, ${ }^{19}$ WoRMS $^{20}$ and Abbott $^{21}$ in detailed (Table 1) (Figure 2).

\section{Characteristics of cowry shells}

Cowry shells are of elongated oval form with the spire mostly or wholly enclosed in the body whorl, and with a long narrow aperture and a canal at both ends. One or both lips are ornamented with a series of ridges at right angled to the aperture. In life the shell is concealed by overthrown mantle lobes and lacks periostracum and hence presents a smooth, polished surface due to deposition of an enamel, hence the name porcelain shells often applied to cypraeidae. As the shell is concealed from view, it is rather mysterious that it is usually strongly coloured, often having app atern of brown spots on a lighter background.

The numerous species of Cypraea are found mainly in the IndoPacific region. ${ }^{17}$ The young Cypraea differs much from the adult and attains the adult aspect by the in rolling of the lips and enclosure of the spire. The mantle lobes thrown over the shell are often tuberculate or papillate and may be coloured.

\section{Characteristics of family Cypraeidae Rafinesque, 18 I 5}

The shell is small to large, ventricose, usually thick, roundly inflated, generally smooth and polished covering with the shining enamel callus, ovate to cylindric ovate. The spire is concealed by the callus presenting only the large body whorl in adult, but the shell is this with a prominent spire with a wide aperture in young stages. Thus, the young shell may be mistaken for different species.
The ventral side of the shell is rather flat. The aperture is long and narrow with a short canal at each end and crenulations on the calloused parietal wall and the inflected outer margin are distinctly formed. There is no operculum. The animal covers the shell by the mantles which meet at the middle of the back.

\section{Characteristics of genus Cypraea Linnaeus, 1758}

Shells large, medium, or small; white or decorated with spots, dots, circles, and rings on stringes; shape oval, elongate oval, or rhomboidal; colour various. Spire concealed under body whorl. Aperture long and narrow, channeled at both ends. Both lips with teeth. No operculum.

\section{Key characteristics of Cypraea species in the study} area

a. Cypraea tigris Linnaeus, 1758: Numerous black dots on white surface, sides with white spots, base also white (Figure 2A).

b. C. miliaris Gmelin, 1791: Shell thin, white spots numerous, on olive gray, no gands on back, sides with reddish brown (Figure 2B).

c. C. mauritiana Linnaeus, 1758: Shell jump-backed, stocky, pink brown spots on deep mahogany, sides deep brown or nearly black, strong dark brown teeth with white in between, base dark brown (Figure 2C).

d. C. thersites Gaskoin, 1849: Rich brown mottings almost black, strong teeth on white base (Figure 2D).

e. C. arabica Linnaeus, 1758: Irregular markings on gray-blue surface, base pale flesh-brown (Figure 2E).

f. C. scurra Gmelin, 1791: Bluish brown surface covered with a network of brown, brown between lip-teeth (Figure 2F).

g. C. eglantina Duclos, 1833: Light greenish brown surface interrupted with uneven dark brown dashes, base whitish (Figure 2G).

h. C. talpa Linnaeus, 1758: Surface chocolate brown, traversed by alternate bands of light brown and white, sides also dark brown (Figure 2H).

i. C. argus Linnaeus, 1758: Shell pale, scattered with a number of brown rings, aperture fairly wide, lip-teeth brown, base light flesh-brown with two dark brown blotches at the middle (Figure 2I).

j. C. erosa Linnaeus, 1758: Somewhat hexagonal in shape, surface speckled with minute white dots, lip-teeth on outer lip extends over base, a large brown blotch on each shell margin (Figure 2J).

k. C. labrolineata Gaskoin, 1849: Surface yellowish brown with a number of white spots of varying sizes, shell thin, teeth not strong (Figure 2K).

l. C. caputserpentis Linnaeus, 1758: Surface with many small white spots surrounded by deep reddish brown colour, base with fading shades of brown (Figure 2L).

m. C. nucleus Linnaeus, 1758: Surface with numerous small knobs and a middle line crease, colour grayish and sides yellowish brown, base sparsely covered by crossing ribs (Figure 2M). 
n. C. isabella Linnaeus, 1758: Surface fawn colour, both ends dark red with two distinct white bands encircling the body. The base is white on one side and coloured the same as its upper portion (Figure $2 \mathrm{~N}$ )

o. C. cicercula Linnaeus, 1758: It has a plump form. Surface light yellow with a small groove at the posterior end, lip-teeth with very prominent ridges (Figure 2O).

p. C. globulus Linnaeus, 1758: Shell globose, surface light eggyolk coloured, but numerous brown dots scattered all over, ridges on lip-teeth less prominent (Figure 2P)

q. C. lynx Linnaeus, 1758: Shell oval, a sprinkling of dark dots all over the surface, basically grayish blue but with an orange brown dorsal line, white base ornamented by orange red in between the long teeth (Fig. $2 \mathrm{Q}$ ).

r. C. asellus Linnaeus, 1758: Surface with three chocolate dark brown bands and two narrow white bands on creamy white coloured surface, both ends hardly rostrated (Figure 2R).

s. C. saulae Gaskoin, 1843: Fawn colour with a distinct brown patch on its back, sides with few brown small spots, sides dotted with brown (Figure 2S).

t. C. teres Gmelin, 1791: Surface light brownish-gray, shaded with brown mottlings, white patches also present, aperture wide, sides with black dots (Figure 2T).

u. C. reevei Gray, 1832: Size medium, surface pinkish brown, lightly banded, single dark dot at pinkish tip (Figure 2U).

Cowry shells were generally associated with coral reefs (Table 2). Feed most actively at night, browsing on encrusting algae and sponges or tiny animals that grow on rock and coral. Juvenile shell strinkingly different from the adults: thin and resembling an olive shell in shape, with a pointed spire, a wide aperture and a sharp, untoothed outerlip. ${ }^{17}$

Then, the shell cannot increase in size but is thickened by deposition of material over the whole surface, producing the glossy aspect and the distinctive adult colour pattern. Though cowries have been traditionally used as food by native fishermen in many parts of the area, they are nowadays mainly collected for their highly prized shell, for collection purposes or for the shell craft industry. ${ }^{17-19}$

Cypraeidae, the largest prosobranch family with 21 species were zonal distributed from intertidal to subtidal water in Andrew Bay and adjacent coastal areas (Table 3). Most members of the family occurs around Geik Taw, Pearl Is., Thanban Gyaing, Abae Chaung, Thanbayar Gyaing, Mayoe Bay, Kathit Is., Thabyu Gyaing, Ponenyat Gyaing, Kwinwine Gyaing, Kyauk pone gyi hmaw and Maung shwe lay Gyaing.

As in the case of family Cypraeidae, many species are occurring very rarely. Thus, Cypraea thersites, C. globulus, C. lynx, C. asellus and $C$. reevei are collected singly from their localities. The other rare species, collected more than one but less than five in number include C. labrolineata, C. nucleus, C. isabella, C. cicercula and C. saulae. The common forms are C. tigris, C. mauritiana, C. arabica and $C$. eglantina. Very abundant species occurring with high frequencies are C. caputserpentis. The family also contains many species which are indeterminable.
Myanmar also utilized gastropod shells for preparing indigenous medicine. Species used for this purpose include many species of Cypraea. Of all the shells prized and treasured by man, the cowries must surely hold pride of place. The best known and one of the largest and handsomest is the tiger cowry, Cypraea tigris which is not striped like the tiger, as one would imagine from its name, but richly spotted like the leopard. ${ }^{5-7}$ In study areas, the tiger cowry has been made into salt cellars, ring stands, snuff boxes, ink holders and mounted as soup spoon or ladels. For personal adornment, shells have surely been more widely used than any other product of nature. The convenient little money cowry, apart from its many uses as currency and ornament has long been a favourite counter in playing games of chance.

\section{Conclusion}

In the present study, a total of 21 species of cowry shells were collected at Andrew Bay and adjacent coastal areas. The identification is done on the basic of external morphological characters. Shells are fairly sturdy, ovate or oblong, spire short and concealed under body whorl in the adult. Surface is highly polished, smooth and usually vividly patterned, with a low groove on midline of the dorsal side. Periostracum absent. Ventral side of the shells are more or less flattened to calloused. Aperture is long and narrow, extending almost the full length of shell, shortly channeled at both ends. Both lips with raised transverse ridges or teeth, the outer one thickened and incurved; inner lip with a shallow longitudinal furrow situated towards front end. No operculum. Mantle very large, with 2 lobes expanding in life over the shell and meeting along the dorsal groove. Mantle lobes often brightly coloured and with numerous small, finger-like or branched sensory outgrowths. Most of the shells are associated with coral reef and rock platforms. Frequently collected throughout the Andrew Bay areas, mainly for its shell which is used in local food and handicrafts. This study supports for conservation and better management of cowry shell species in Myanmar water.

\section{Acknowledgements}

I am indebted to Dr Aung Myat Kyaw Sein, Rector of Mawlamyine University and Dr Mie Mie Sein and Dr San San Aye, Pro-Rectors of Mawlamyine University, for their encouragement and supports in preparing this work. I am very grateful to Dr San Tha Tun, Professor and Head of the Department of Marine Science, Mawlamyine University, for his valuable suggestions and constructive criticisms on this study. I would like to express my sincere thanks to colleagues of Andrew Bay Observation Group, Department of Marine Science, Mawlamyine University, for their kindly help me in many ways during field trips. Many thanks go to Daw Lwin Lwin, Retired Lecturer of the Department of Marine Science, Mawlamyine University, for her assistance in preparations of the manuscript. I would like to thank my beloved parents, U Win Maung and Daw Than Than Aye, for their physical, moral and financial supports throughout this study.

\section{Funding}

None.

\section{Conflicts of interest}

The author declares that there are no conflicts of interest. 
